\title{
Por una crítica curiosa. Las políticas del ensayo y la teoría queer ${ }^{1}$
}

\author{
2. Alberto Giordano / Universidad Nacional de Rosario - CONICET \\ albertogiordanos9@gmail.com
}

\section{Resumen}

Este trabajo propone una evaluación ética del recurso a la "queer theory» en ensayos literarios sobre subjetividades anómalas, escritos en contextos académicos. Las reflexiones se sitúan en un contexto metodológico específico: la conveniencia de contextualizar la experimentación con lo singular de la voz narrativa y las voces narradas, en las primeras novelas de $\mathrm{Ma}$ nuel Puig, remitiéndose a las poéticas y las políticas de lo camp, en las que adquiriría visibilidad social la identidad queer. La heterogeneidad entre identidad minoritaria y devenir-menor, entre la producción de diversidades y la afirmación de una diferencia en sí, explicaría la necesidad de desprender la literatura de Puig de su identificación con las políticas y las poéticas de lo camp, después de haber encontrado en ellas un marco apropiado para evaluar el sentido y la fuerza de su intervención institucional. El trabajo concluye con una especulación sobre la heterogeneidad entre las versiones del concepto de experiencia que presuponen las políticas de la «crítica gay» y las del ensayo: las primeras conciben la experiencia como narrativización de identidades construidas socialmente; las segundas, como la afirmación de los sinsentidos que le dan a la vida un sentido problemático.

\section{Abstract}

This paper proposes an ethical evaluation of the use of "queer theory" in literary essays about abnormal subjectivities, written in academic contexts. The reflections are placed in a specific methodological context: the need of contextualize the experimentation with the particular of the narrative voice and the narrated voices, in the Manuel Puig's first novels, referring to the poetics and politics of the camp, in which queer identity acquires social visibility. Heterogeneity between minority identity and becoming-minor, between the diversities's production and the affirmation of difference in itself, explain the need to detach Puig literature of the identification with the politics and poetics of the camp, after having found in them an appropriate framework to assess the meaning and force of its institutional intervention. The work concludes with an speculation on the heterogeneity between the versions of the concept of experience that "critical gay» politics presuppose and those of the essay: the first one, conceive the experience as narrativization of socially constructed identities; the second one, as the affirmation of nonsenses that give life a problematic meaning. 